\title{
Model Pewarisan Cerita Rakyat melalui Lomba Storytelling
}

\author{
Nur Israfyan Sofian ${ }^{1}$
}

\begin{abstract}
Abstrak
Makalah ini bertujuan untuk memaparkan hasil pengamatan saya tentang upaya pemertahanan cerita rakyat melalui lomba strorytelling bagi siswa sekolah menengah. Lomba storytelling adalah salah satu mata lomba yang ada di gelaran English Expo dan diadakan setiap tahun oleh mahasiswa Jurusan Pendidikan Bahasa Inggris FKIP Universitas Halu Oleo. Cerita rakyat, oleh setiap siswa peserta lomba, diterjemahkan ke dalam Bahasa Inggris dan dipertunjukkan. Hasil temuan saya menunjukkan bahwa lomba storytelling menjadi ajang pewarisan cerita rakyat. Proses pewarisan cerita rakyat melalui lomba storytelling tidak saja berefek kepada tersampaikannya cerita rakyat yang mengandung konsep kebudayaan masyarakat pemilik cerita rakyat tetapi juga menjadi ajang pemahaman lintas kebudayaan bagi anak-anak seusia sekolah menengah. Lebih lanjut, mereka dapat menjadi agen budaya dalam memperkenalkan konsep kebudayaan melalui lomba storytelling.
\end{abstract}

Istilah kunci: storytelling, pewarisan dan pemahaman lintas budaya.

\begin{abstract}
This paper aimed to tell about my review of maintaining folktale through storytelling competeition for junior high students. Storytelling competition is one of annual competition under English Expo event held by the Students of English Department in Education Faculty, Univercity of Halu Oleo. Every folktale was interpreted from local language into Bahasa and then into English and finally performed as storytelling. The result of this review showed that storytelling competition for junior high school students was a inheritance model for folktale. The inheritance process had positive effects not only to convey the concept of culture but also for cross cultural understanding, mainly for junior high school students. the students may also become the cultural agents to introduce cultural concepts through storytelling.
\end{abstract}

Keyterms: storytelling, inheritance, cross cultural understanding.

\section{Pendahuluan}

Perhelatan English Expo adalah kegiatan lomba yang digagas oleh mahasiswa Jurusan Pendidikan Bahasa Inggris di Fakultas Keguruan dan Ilmu Pendidikan Universitas Halu Oleo, Provinsi Sulawesi Tenggara. Salah satu mata lomba yang dipertandingkan dan merupakan fokus dalam tulisan ini adalah lomba storytelling. Lomba storytelling di sini merupakan kegiatan berkisah tentang cerita rakyat yang diangkat dari cerita rakyat di wilayah Sulawesi Tenggara. Pada lomba storytelling yang dilaksanakan pada di English Expo 2016, ada tiga buah cerita rakyat pilihan panitia yang diperlombakan yakni "Asal mula nama Gunung Mekongga" dari Kolaka, "La Sirimbone" dari Muna dan "La Onto Ontolu" dari Buton.

\footnotetext{
${ }^{1}$ Staf pada Fakultas Ilmu Budaya Universitas Halu Oleo. Lahir di Gu-Buton pada 8 April 1986.

Alamat pos-el: rien_sofian@yahoo.co.id
} 
Seperti umumnya lomba storytelling, peserta lomba menentukan satu cerita rakyat yang mereka kisahkan di hadapan juri dan penonton. Cerita rakyat yang dibagikan oleh panitia berupa teks tertulis berbahasa Indonesia dan umum dikenal oleh masyarakat pemiliknya. Para peserta lomba di tahun 2016 berjumlah kurang lebih 30an orang, diminta untuk membaca dan memahami kronologi ceritanya dengan benar untuk diceritakan kembali ke dalam Bahasa Inggris. Karena ini adalah lomba storytelling, maka peserta tidak dibenarkan membaca teks atau menghafalkan cerita dalam lomba. Akan tetapi, peserta diminta untuk bercerita secara alami sesuai dengan hasil interpretasi mereka disertai gestur dan mimik yang tepat serta suara yang dibuat semenarik mungkin sesuai dengan tuntutan cerita.

Tulisan ini merupakan laporan atas hasil pengamatan saya terhadap bentuk pemertahanan cerita rakyat sebagai sebuah tradisi lisan di dalam masyarakat pemiliknya. Yang menjadi fokus adalah proses pewarisan yang terjadi. Selain itu, akan dibahas juga efek positif yang dapat ditimbulkan oleh proses pewarisan ini.

\section{Lomba Storytelling Sebagai Sebuah Proses Pewarisan.}

Di bagian awal tulisan ini telah saya sebutkan bahwa peserta yang mengikui lomba storytelling tingkat SMP dalam English Expo 2016 berjumlah 30an orang. Kesemua peserta ini berasal dari beberapa wilayah di Sulawesi Tenggara yakni Baubau, Raha, Kolaka serta Kendari. Proses pewarisan yang terjadi dalam kegiatan ini nyaris tanpa disadari oleh si penerima. Peserta lomba memusatkan perhatiannya pada kisah cerita hanya untuk keperluan pertunjukan yang akan diikutinya dalam sebuah ajang perlombaan.

Contoh yang menarik perhatian saya adalah tentang seorang peserta yang berasal dari Kota Kendari dan beretnis Tionghoa. Siswa ini bercerita tentang kisah La Onto-ontolu, cerita rakyat yang berasal dari daerah Buton. La Onto-ontolu, berkisah tentang seorang pemuda yang berasal dari sebuah telur karena dikutuk setelah melakukan sebuah kesalahan. Ketika bercerita, siswa kelas dua SMP tersebut mengilustrasikan bentuk telur dengan menggunakan tangannya untuk menyebutkan kata Ontolu. Kata La Onto-ontolu yang berarti berasosiasi dengan telur (Ontolu artinya telur) tidak diterjemahkan menjadi egg ketika ceritanya diterjemahkan ke dalam Bahasa Inggris. Proses penerjemahan cerita dari bahasa daerah ke Bahasa Indonesia lalu ke Bahasa Inggris tidak berarti menerjemahkan semua kata tetapi ada pengecualian bagi beberapa istilah tertentu.

Ada beberapa alasan yang diindikasikan La Onto-ontolu ini tidak diterjemahkan. Pertama, tentu karena merupakan nama tokohnya. Kedua, kata ini juga menjadi salah satu ciri khas yang dapat menjelaskan dari mana cerita ini berasal, dilihat dari kata yang berasal dari rumpun bahasa Buton. Telur, cukup erat kaitannya dengan kehidupan spiritual masyarakat Buton. Di setiap ritual adat masyarakat Buton, telur adalah salah satu material budaya yang tidak pernah absen. Kata La Onto-ontolu melekat dalam cerita ini akan menjadi salah satu pembawa pesan tentang sistem kognisi masyarakat yang ada di daerah pemilik kebudayaan. Kisah La Onto-ontolu sebagai sebuah cerita rakyat merupakan bagian dari tradisi lisan (Pudentia dan Tol, 1995: 2), utamanya bagi masyarakat Buton. Tradisi lisan dalam bentuk cerita rakyat yang dipentaskan di depan penonton tidak saja mengandung sebuah narasi kronologis yang melibatkan tokoh-tokoh tertentu tetapi juga mengandung kognisi kebudayaan Pudentia (Pudentia: 2010). Kognisi kebudayaan di sini adalah konsepkonsep pengetahuan yang berkaitan erat dengan masyarakat pemiliknya yang dapat menjelaskan tentang pola kehidupan masyarakat pemilik cerita.

Pola pewarisan yang terjadi dalam perhelatan lomba storytelling ini terjadi, seperti saya katakan mula-mula, bisa saja tanpa disadari oleh para pelakunya, utamanya peserta lomba. Proses pewarisan, menurut Vansina (1973), dapat saja terjadi secara spontan tanpa mengindahkan aturan pewarisan yang berlaku. Pemilik dan pewaris dalam konteks ini tidak 
memiliki kontak secara langsung. Akan tetapi, ketentuan lomba membuat si pewaris baru akhirnya memahami ceritanya karena ada kebutuhan untuk menceritakan kembali cerita ini dengan apik ke hadapan publik. Yang menjadi fokus utama dalam proses penceritaan kembali adalah kronologi kisahnya serta tokoh-tokoh yang terlibat. Dalam proses pewarisan, perubahan dalam gaya penutur si pencerita tidak dapat dihindari. Ini dikarenakan konten utama dari cerita seperti tokoh dan kronologi tidak banyak mengalami perubahan. Tuntutan lomba ternyata memiliki kemiripan dengan sistem pewarisan yakni tokoh yang terlibat dan kronologi sehingga proses pewarisan dapat terjadi.

Kondisi ini memperlihatkan bahwa setiap anak, dalam lomba storytelling memiliki peran penting dalam penyebaran salah satu materi kebudayaan. Saya menyebutnya sebagai materi kebudayaan karena, cerita rakyat dalam pandangan Hoed (2008), mengandung sekumpulan pengetahuan. Karena itu, penting kiranya untuk terus melanjutkan pewarisan cerita rakyat agar sistem kognisi dan konsep kebudayaan yang ada di dalam setiap cerita rakyat (Pudentia, 2010) tidak mengendap tetapi dapat tersampaikan kepada masyarakat yang lebih luas, tidak saja untuk pemilik cerita rakyat tersebut.

Maka dari itu, melihat posisi mereka yang becerita di panggung lomba storytelling, dapat dikatakan peserta lomba storytelling tidak saja menjadi active receiver tetapi juga sebagai active transmitter. Pewarisan dapat menjadi cukup efektif karena adanya kontak langsung antara pencerita dan penerima. Lebih lanjut, setiap siswa yang menjadi pencerita diajak untuk masuk ke dalam dunia pemikiran cerita rakyat yang mereka bawakan dan mengalami sendiri proses pewarisan sehingga dapat menceritakan kembali. Akhirnya setiap anak menjadi agen kebudayaan untuk menceritakan kembali apa yang mereka baca meski dikemas dalam bentuk perlombaan.

Karena adanya kontak langsung tersebut, yang akan mendapatkan pengaruh dari pertunjukan ini adalah penonton. Penonton dalam konteks lomba storytelling ini diibaratkan sebagai penerima di mana peserta lomba menjadi pembawa pesan cerita rakyat. Seperti juga performer, penonton yang menyaksikan perlombaan ini terkadang juga tidak mengenal latar tempat yang mereka dengarkan. Akan tetapi, melalui lomba ini terjalin upaya pemahaman lintas budaya (cross culture understanding) yang memungkinkan mereka mempelajari latar budaya lain selama proses lomba berlangsung. Pengetahuan yang terkandung dalam cerita akan tersampaikan bersamaan dengan ketika cerita itu disampaikan. Menegaskan kondisi tersebut, Sedyawati (2006: 420) mengatakan bahwa pewarisan dalam sebuah pertunjukan sebenarnya merupakan sistem pemanfaatan media pertunjukan untuk memperoleh fungsi dan manfaat yang baik. Apakah itu? Akan ada interpretasi baru dari sebuah pemahaman dan penghayatan terhadap isi cerita yang akan dilanjutkan kepada pewaris selanjutnya.

\section{Lomba Storytelling Sebagai Tempat Untuk Pemahaman Lintas Budaya}

Proses pewarisan seperti yang saya sebutkan di atas dapat memberikan beberapa pengaruh positif. Contoh yang saya berikan sebelumnya tentang seorang anak beretnis Tionghoa yang tinggal di Kendari dan menjadi peserta lomba. Kisah yang diangkat oleh si anak adalah cerita rakyat berjudul La Onto-ontolu. Ketika sedang mempertunjukkan kemampuannya berstorytelling si anak tampak kikuk mengucapkan kata La Onto-ontolu. Kata La Onto-ontolu bukanlah kata atau nama yang familiar bagi indra pendengar juga pengucapnya. Akan tetapi, ketentuan lomba mengahruskannya untuk tidak saja memahami makna kata tetapi juga konteksnya. Sudah tentu jika terlalu dini untuk menegaskan pemahaman menyeluruh tentang apa yang dia peroleh dalam proses pertukaran budaya bagi si anak yang berusia di kisaran 13 hingga 15 tahun ini. Akan tetapi, tanpa kita sadari telah terjadi proses pemahaman lintas budaya di sini. Ukuran paling minimal yang bisa kita lihat adalah si anak telah mengetahui bahwa kata telur dalam Bahasa Indonesia memiliki padanan kata Ontolu bagi orang Buton. Terlihat dari cara siswa tersebut ketika menggambarkan bentuk telur melalui tangannya 
ketika sedang bercerita. Ini merupakan bentuk interpretasi si siswa peserta lomba terhadap cerita rakyat yang sedang dibacakannya. Bentuk interpetasi ini diimplementasikan dalam bentuk sebuah analogi dipadu dengan teknik bercerita dan gerak tubuh untuk menguatkan isi cerita.

Interpretasi yang lebih luas terjadi salah satunya karena adanya proses penerjemahan. Cerita rakyat ini mengalami dua proses penerjemahan yakni dari bahasa asli (bahasa daerah) ke Bahasa Indonesia lalu ke Bahasa Inggris. Proses penerjemahan adalah bentuk interpretasi lebih lanjut dan dalam koridor yang baik ketika tetap mempertahankan esensi utamanya ketika menyebut kata Ontolu. Konsistensi dalam menyebut kata Ontolu adalah upaya untuk mempertahankan konteksnya yang berarti cerita ini berasal dari tanah Buton, meski dibawakan oleh siswa yang beretnis Tionghoa dengan menggunakan Bahasa Inggris. Kata Ontolu dalam cerita berbahasa Inggris mengisyaratkan kesan keButonan dalam cerita ini. Secara sederhana dapat dikatakan bahwa Ontolu yang berarti telur amat dekat dengan kisah kehidupan orang Buton, seperti disinyalir oleh Engelenhoven ketika mengatakan bahwa sebuah benda atau istilah yang ada di dalam cerita rakyat ataupun nyanyian rakyat berasosiasi sangat dekat dengan pemilik cerita atau lagu tersebut (Sofian, 2014). Upaya penerjemahan dengan mempertahankan konteks ternyata dilakukan oleh siswa peserta storytelling tersebut. Akhirnya, membawa cerita rakyat dalam ragam yang lebih variatif ternyata memiliki peran yang cukup siginifikan dalam menyebarkan dan mewariskan sebuah konsep kebudayaan.

Adanya proses interpretasi ini dapat menunjuang proses pemahaman lintas kebudayaan. Terjemahan, tidak dapat dipungkiri, adalah salah satu cara dalam menyebarkan materi kebudayaan, salah satunya cerita rakyat. Dalam konteks lomba storytelling, seorang siswa yang beretnis Tionghoa dan berkisah tentang cerita rakyat yang berasal dari daerah Buton adalah salah satu contoh kecil yang dapat bermakna besar, tidak saja bagi si anak tetapi pada proses pewarisan cerita rakyat dari tanah Buton.

\section{Simpulan}

Lomba storytelling yang diselenggarakan oleh mahasiswa Jurusan Pendidikan Bahasa Inggris FKIP UHO dilaksanakan setahun sekali. Seorang peserta lomba dapat mengenal dan mempelajari sebuah bahkan lebih cerita rakyat setiap kali mengikuti lomba storytelling ini. Untuk memahami dan memilih sebuah cerita, seorang anak akan membaca dulu isi semua cerita yang ada. Setiap anak, dalam masa menjadi siswa SMP, dapat mengikuti lomba storytelling lebih dari sekali; bisa dua bahkan hingga tiga kali. Ini artinya, semakin banyak perbendaharaan cerita rakyat bagi setiap anak peserta lomba. Di sinilah peran sang anak sebagai seorang agen budaya serta pemahaman lintas budaya dapat menjalankan fungsinya.

Fungsi tersebut akan semakin berjalan dengan baik jika guru memahami kondisi ini tidak saja melibatkan anak ini sebagai storyteller di lomba yang dia ikuti tetapi juga di kelas atau bahkan di sekolah. Efeknya, akan memotivasi siswa yang lain untuk mengikuti lomba storytelling serta untuk menjadi ajang latihan bagi sang siswa sebelum atau sesudah lomba. Di sini peran siswa, guru dan panitia lomba memiliki posisi penting dalam proses pewarisan sebuah kognisi kebudayaan di lingkungan pendidikan formal.

Lebih lanjut, dengan adanya lomba storytelling seperti ini, akan banyak kemungkinan untuk menggali lebih banyak cerita rakyat di dalam masyarakat. Semakin banyak cerita yang dijadikan materi lomba dan diperkenalkan kepada setiap anak, semakin banyak konsep kebudayaan yang akan dikenali setiap anak. Selain itu, efek dari lomba storytelling adalah selain memungkinkan terjadinya proses pewarisan secara berkesinambungan juga merupakan ajang pemahaman lintas kebudayaan. Setiap siswa yang menjadi peserta atau bagi mereka yang menonton akandapat mengenali sedikitnya satu konsep kebudayaan yang ada dalam cerita rakyat yang dilombakan. 


\section{Referensi dan Sumber Bacaan}

Hoed, Benny Hoedoro. 2008. Komunikasi Lisan sebagai Dasar Tradisi Lisan (dalam Metodologi Kajian Tradisi Lisan). Pudentia MPSS (Editor). Jakarta: ATL

Lenox, Mary F. 2000. Storytelling for Young Children in A Multicultural World dalam Early Childhood Education Journal, Vol. 28, No. 2. Tidak ditemukan lokasi penerbitan. Diakses pada 18 Agustus 2017, pukul 04.30 dari warehouse.olc.edu/ khecrow/webfolder/ Research/Lenox.pdf

Pudentia, MPSS. 2010. The Revitalization of Mak Yong in the Malay World dalam Jurnal Wacana Vol. 12 No.1. April 2010. Jakarta: Yayasan Obor Indonesia

Pudentia dan Rodger Tol. (1995). "Oral Traditions From The Indonesian Archipelago A Three-Directional Approach", Warta ATL, I, No.1/01 Maret, hlm 12.

Sedyawati, Edi. 1996. Kedudukan Tradisi Lisan dalam Ilmu-Ilmu Sosial dan Ilmu-Ilmu Budaya, (dalam Warta ATL Jurnal pengetahuan dan Komunikasi Peneliti dan Pemerhati Tradisi Lisan). Edisi II Maret. Jakarta: ATL

Sofian, Nur Israfyan. 2014. Lariangi pada masyarakat Kaledupa di Wakatobi Sulawesi Tenggara (sebuah tinjauan pewarisan). Universitas Indonesia: Tesis (tidak diterbitkan).

Vansina, Jan. 1973. Oral Tradition. Great Britain: Penguin Books. 